BRANKA V. KALUĐEROVIĆ ${ }^{*}$, DJURO ČOKEŠA ${ }^{1}$, VLADIMIR DODEVSKI ${ }^{1}$, SANJA KRSTIĆ ${ }^{1}$, VLADISLAVA M. JOVANOVIĆ ${ }^{2}$

${ }^{1}$ University of Belgrade, Institute of Nuclear Sciences Vinča, Belgrade, Serbia, ${ }^{2}$ University of Belgrade, ICTM - Department of electrochemistry, Belgrade, Serbia
Scientific paper

ISSN 0351-9465, E-ISSN 2466-2585

UDC:669,218.5:669.238.5(n)

doi: $10.5937 / Z a s M a t 1504409 \mathrm{~K}$

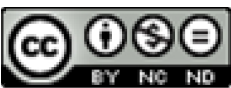

Zastita Materijala 56 (4)

409 - 412 (2015)

\title{
Direct synthesis of noble metal nanostructures on carbon support by hydrothermal process
}

\begin{abstract}
Nanostructures of noble metals (Pt and $\mathrm{Ag}$ ) on carbon support were prepared from fructose and solution of the Nobel metal salts $\left(\mathrm{H}_{2} \mathrm{PtCl}_{6} \times 6 \mathrm{H}_{2} \mathrm{O}\right.$ or $\left.\mathrm{AgNO}_{3}\right)$ under hydrothermal conditions. Commercial fructose $\left(\mathrm{C}_{6} \mathrm{H}_{12} \mathrm{O}_{6}\right)$ acts as the carbon source and reducing agent and noble metal salts is a source of the metal to be incorporated in the new formed carbon material structure. The crystalline structure was examined by X-ray diffraction (XRD) and morphology investigated by scanning electron microscopy (SEM). The crystallite size of the deposited particles could be estimated by evaluating the line width of the Bragg peak applying the Scherrer method. All the $X R D$ patterns clearly show the five main characteristic peaks of the face-centered cubic (fcc) crystalline for both Pt and Ag crystallite. The obtained Pt crystallite sizes were below $5.5 \mathrm{~nm}$, while the Ag crystallite sizes were about 32 or $34 \mathrm{~nm}$.
\end{abstract}

Keywords: hydrothermal process, platinum, silver, nanostructure, crystallite size.

\section{INTRODUCTION}

Among various technologies available today in materials processing, the hydrothermal technique occupies a unique place due to its advantages over conventional technologies. However, it is a simple method where the solvent (usually water) is heated in a sealed vessel to a temperature above its boiling point. In that way generated autogenous pressure far exceeds ambient pressure which automatically raises the effective boiling point of the solvent.

It covers processes like: hydrothermal treatment, hydrothermal crystal growth leading to the preparation of fine to ultra-fine crystals, bulk single crystals, hydrothermal synthesis, hydrothermal decomposition, hydrothermal sintering, hydrothermal transformation, hydrothermal stabilization of structures, hydrothermal carbonization, etc. [1]. Hydrothermal carbonization (HTC) is an alternative way to pyrolysis or charcoal making for carbon materials production $[2,3]$. In recent years, there have

\footnotetext{
*Corresponding author: Branka Kaluđerović

E-mail: branka@vin.bg.ac.rs

Paper received: 16. 05. 2015.

Paper accepted: 19. 07. 2015.

Paper is available on the website: www.idk.org.rs/casopis
}

been a great number of reports regarding sizecontrolled carbon microspheres synthesized via hydrothermal treatment of biomass from poly- $[2,3]$ to mono-saccharides (especially fructose and glucose) [4-7].

Commercially, fructose is derived from sugar cane, sugar beets etc. In aqueous solution, fructose exists as an equilibrium mixture of $70 \%$ fructopyranose and about $22 \%$ fructofuranose, as well as small amounts of three other forms, including the acyclic structure. Fructose readily dehydrates to give hydroxymethylfurfural (HMF). HMF was formed by intramolecular dehydration and subsequent aromatization and polymerization formed microscopic nonpolar carbon-containing spheres that spontaneously assemble. Subsequent loss of water by these assemblies leads to further coalescence of microscopic spheres to larger spheres, thereby generating a grain-like surface morphology.

It well known that the deposition of noble metal nanoparticles on carbon surfaces occurs after the activation of the carbon material surface. In that way acid surface groups are formed on the surface, some of which are able to reduce noble metal ions from solution [8-10]. 
Platinum supported on carbon material is one of the most intensively studied catalysts because of its possible application in fuel cells.

Silver exhibits the largest electrical and thermal conductivities among all the metals and its nanoparticles form have found wide applications in catalysis, electrocatalysis, environment protection, antimicrobials, chemical sensors, conductive inks and electronic devices [8].

A great number of practical and potential applications in areas such as energy storage, catalysis and environment protection have been launched based on carbon nanomaterials as well as on noble metal on carbon material support.

In this report noble metal nanostructures with carbon material as a support were produced in one step by the hydrothermal process. The resulting carbon materials were characterized by scanning electron microscopy (SEM) and X-ray diffraction technique (XRD).

\section{EXPERIMENTAL PART}

In an experiment, $5 \mathrm{~g}$ fructose, were dissolved into $40 \mathrm{ml}$ of solution of $6 \mathrm{mmol} / \mathrm{dm}^{3} \mathrm{H}_{2} \mathrm{PtCl}_{6}$ dissolved in $0.1 \mathrm{~mol} / \mathrm{dm}^{3} \mathrm{HCl}$ in a glass reactor. Solution was mixed with magnetic stirrer at room temperature for one hour.

After that reactor was sealed and placed in the dryer and then temperature is adjusted at $150^{\circ} \mathrm{C}$ and maintained 66 hours. After that samples were filtered and washed with distilled water for several times. Finally, the samples were dried in dryer at $100^{\circ} \mathrm{C}$ for few hours. This sample was termed as $\mathrm{Pt} / \mathrm{C}$.

Preparation of samples with silver was performed in similar way, but we used two different weights of fructose: 6 and $1.5 \mathrm{~g}$. The solution was $7.4 \mathrm{mmol} / \mathrm{dm}^{3} \mathrm{AgNO}_{3}$ dissolved in $40 \mathrm{ml}$ of 0.1 $\mathrm{mol} / \mathrm{dm}^{3} \mathrm{HNO}_{3}$. The rest of the procedure was the same as was for the preparation of sample with platinum. These samples are labeled as Ag1/C (prepared from $6 \mathrm{~g}$ of fructose) and $\mathrm{Ag} 2 / \mathrm{C}$ (prepared from $1.5 \mathrm{~g}$ of fructose).

The morphology and structure of the products were characterized by X-ray diffraction (XRD) with $\mathrm{CuK}_{\alpha}$ radiation and scanning electron microscopy (SEM).

An advantage of XRD is also that this method provides a very simple possibility for estimating the particle size (L) [11-13] from the broadening of the XRD reflections by means of the Scherrer formula equation (1).

$$
L=0.9 N(\beta \cos \theta)
$$

where:

$\lambda$ is the X-ray wavelength; $\lambda=0.154056 \mathrm{~nm}$;

$\beta$ is the line broadening at half the maximum intensity (FWHM), after subtracting the instrumental line broadening (according to equation (2)), and $\beta$ is in radians;

$\theta$ is the angle of the considered Bragg reflection.

$$
\beta=\ell^{-}\left(\beta_{\text {observed }}^{2}-b^{2}\right)
$$

where:

$\beta_{\text {observed }}$ is FWHM reflection, observed;

$\mathrm{b}$ is the is FWHM instrumental correction.

\section{RESULTS AND DISCUSSION}

Noble metal/Carbon materials were prepared by hydrothermal carbonization process using fructose to acts as the carbon sources and reducing agents, and platinum or silver salts as catalysts for the carbonization process and source of the metals to be encapsulated.

All the samples were characterized by XRD measurements in order to verify the deposition of platinum or silver and to check the crystallinity of the noble metal particles.

The spectrum of the Pt/C sample is shown at Figure 1. The first observed broad peak at $2 \theta=$ $20.158^{\circ}$ is (002) diffraction from amorphous carbon which is consistent with reports from other authors for amorphous carbon obtained by HTC [14]. Further peaks placed at $39.625^{\circ}, 46.040^{\circ}, 67.306^{\circ}$, $81.234^{\circ}$ and $85.569^{\circ}$ (see Figure 1 and Table 1) are associated to the (111), (200), (220), (311), and (222) planes, respectively of the face-centered cubic (fcc) crystalline Pt.

Table 1 - Peak position ( $\left.2 \theta_{\max }\right)$, crystallite size (L) and interplanar distance (d) for different reflections of $\mathrm{Pt} / \mathrm{C}$ sample

\begin{tabular}{|c|c|c|c|c|}
\hline Reflection & 111 & 200 & 220 & 311 \\
\hline $2 \theta_{\max }\left({ }^{\circ}\right)$ & 39.68 & 46.075 & 67.367 & 81.18 \\
\hline$d(n m)$ & 0.22696 & 0.19684 & 0.13889 & 0.11839 \\
\hline$L(n m)$ & 5.39569 & 4.7211 & 4.60605 & 5.12638 \\
\hline
\end{tabular}

The crystallite size $(L)$ of the Pt crystallites is estimated from the line broadening for all reflections (except for (222) reflection) and with the 
interplanar distances, are presented in Table 1. $5.4 \mathrm{~nm}$ calculated from (220) and (111) reflections, Platinum crystallite size is in the range from 4.6 to respectively.

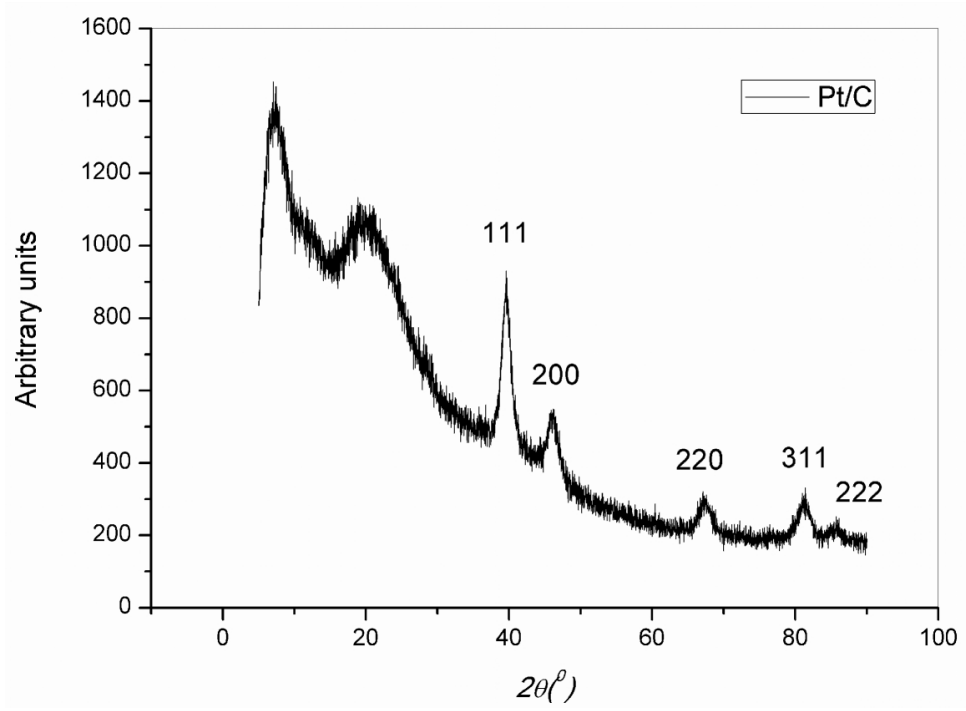

Figure 1 - X-ray diffraction of Pt/C sample

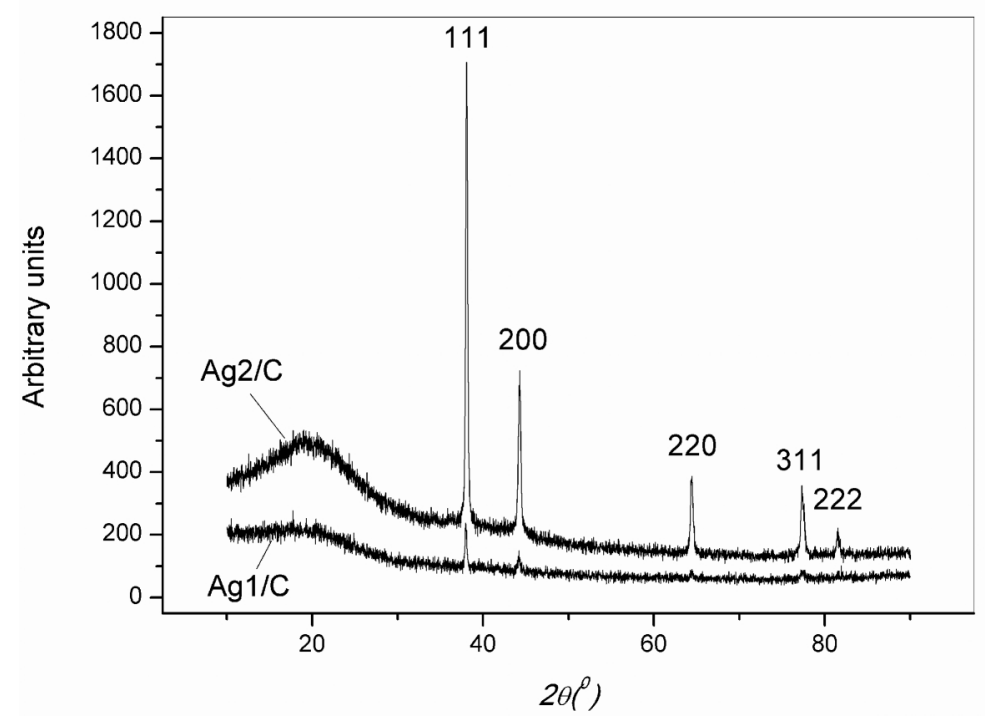

Figure 2 - X-ray diffraction of Ag/C samples

The spectrum of the $\mathrm{Ag} / \mathrm{C}$ samples is shown at Fig.2. All the prominent peaks placed at $\sim 38^{\circ}$, $\sim 44^{\circ}, \sim 64^{\circ}, \sim 77^{\circ}$, and $\sim 81.4^{\circ}$ are representing the (111), (200), (220), (311) and (222) Bragg's reflections, respectively, from crystal planes of face centered cubic (fcc) structure of silver. Ag2/C sample that were prepared with a smaller content of fructose in the starting mixture, have more pronounced peaks than sample Ag1/C. Silver crystallite size, obtained from its (111) reflection is $34.08 \mathrm{~nm}$ for sample $\mathrm{Ag} 1 / \mathrm{C}$ and for sample Ag2/C is slightly smaller $(32.27 \mathrm{~nm})$.

Presence of silver in the sample Ag1/C was not observed by SEM analysis, due to the large amount of carbon (see Figure 3). Dendritic structure of silver was observed in the sample Ag2/C (see Figure 4).

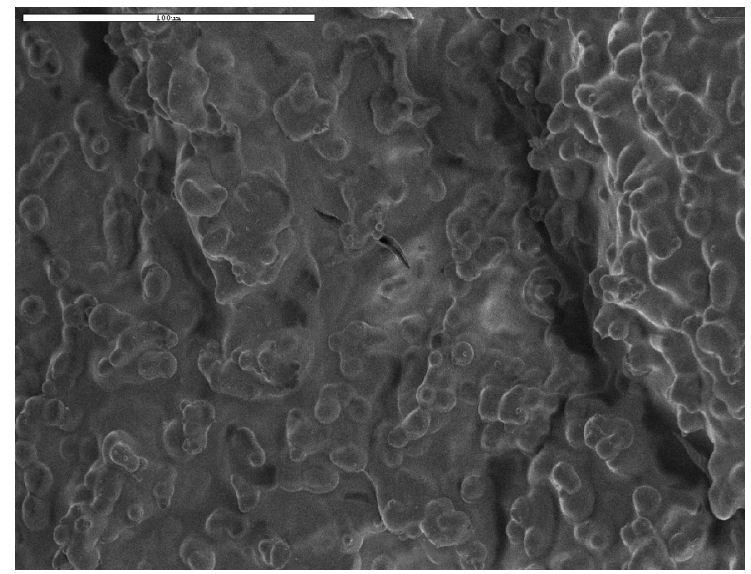

Figure 3 - SEM micrograph of sample Ag1/C 


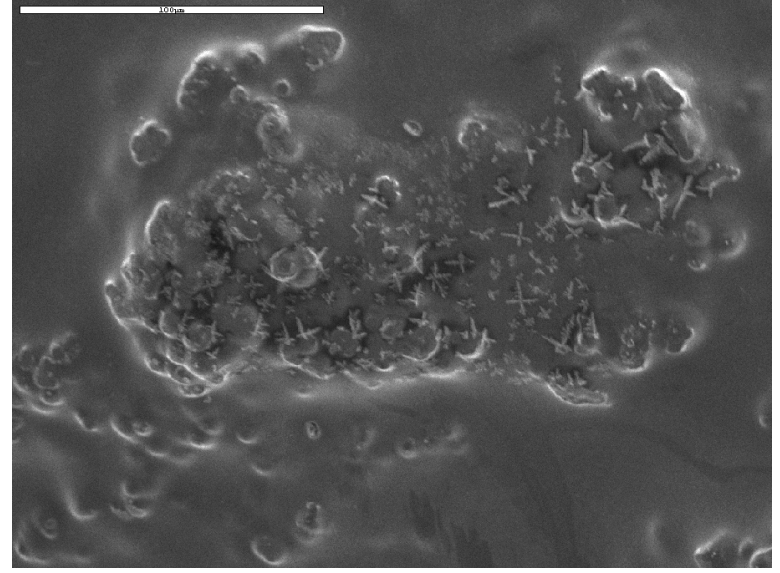

Figure 4 - SEM micrograph of sample Ag2/C

\section{CONCLUSION}

The hydrothermal process using commercial fructose as carbon source and salt as noble metal source produces carbon materials with incorporated nanoparticles of Pt or Ag. The X ray diffractograms of obtained materials showed the typical fcc structure for both noble metals. The results also confirmed presence of nanosized noble metals crystallites. The Ag dendrites are single-crystalline materials.

\section{Acknowledgements}

The financial support of this research work was provided by the ministry of Education and Science of the Republic of Serbia through the project III-45005.

\section{REFERENCES}

[1] K.Byrappa, T.Adschiri (2007) Hydrothermal technology for nanotechnology, Prog. Cryst. Growth Character. Mater., 53(2), 117-166.

[2] M.M.Titirici, A.Thomas, S.-H.Yu, J.O.Müller, M. Antonietti (2007) A direct synthesis of mesoporous carbons with bicontinuous pore morphology from crude plant material by hydrothermal carbonization, Chem. Mater., 19(17), 4205-4212.
[3] R.Demir-Cakan, N.Baccile, M.Antonietti, M.M.Titirici (2009) Carboxylate-rich carbonaceous materials via one-step hydrothermal carbonization of glucose in the presence of acrylic acid, Chem. Mater., 21(3), 484-490.

[4] X.M.Sun, Y.D.Li (2004) Colloidal Carbon Spheres nad theis core/shell structures with noble-metal nanoparticles, Angew. Chem., Int. Ed., 43(5), 597601.

[5] Q.Wang, H.Li, L.Q.Chen, X.J.Huang (2001) Monodispersed hard carbon spherules with uniform nanopores, Carbon, 39(14), 2211-2214.

[6] M.Sevilla, A.B.Fuertas (2009) Chemical and structural properties of carbonaceous products obtained by hydrothermal carbonization of saccharides, Chem. Eur. J, 15(16), 4195-4203.

[7] J.Ryu, J.W.Suh, D.J.Suh, D.J.Ahn (2010) Hydrothermal preparation of carbon microsphere from mono-saccharides and phenolic compounds, Carbon, 48(7), 1900-1998.

[8] E.Fortunati, F.D'Angelo, S.Martino, A.Orlacchio, J.M.Kenny, I.Armentano (2011) Carbon nanotubes and silver nanoparticles for multifunctional conductive biopolymer composites, Carbon, 49(7), 2370-2379.

[9] J.Cveticanin, A.Krkljes, Z.Kacarevic-Popovic, M.Mitric, Z.Rakocevic, Dj.Trpkov, O.Neskovic (2010) Functionalization of carbon nanotubes with silver, Appl. Surf. Sci., 256(23), 7048-7055.

[10] Z.Fang, K.Tang, S.Lei, T.Li (2006) CTAB-assisted hydrothermal synthesis of $\mathrm{Ag} / \mathrm{C}$ nanostructures, Nanotechnol., 1712), 3008-3011.

[11] V.Radmilović, H.A.Gasteiger, P.N.J.Ross (1995) Structure and chemical composition of a supported $\mathrm{Pt}-\mathrm{Ru}$ electrocatalyst for methanol oxidation, J Catal., 154(1), 98-106.

[12] K.A.Carrado, G.Sandi, R.Kizilel, S.Seifert, N. Castagnola (2005) Platinum nanoclusters immobilized on polymer-clay nanocomposite films, Appl. Clay Sci., 30(2), 94-102.

[13] S.Zec, S.Bošković, B.Kaluđerović, Ž.Bogdanov, N.Popović (2009) Chemical reduction of nanocrystalline $\mathrm{CeO}_{2}$, Ceram. Int., 35(1), 195-198.

[14] Z.-L.Xie, R.J.White, J.Weber, A.taubert, M.M.Titirici (2011) Hierarchical porous carbonaceous materials via ionothermal carbonization of carbohydrates, J. Mater. Chem., 21(20), 7434-7442.

\section{IZVOD}

\section{DIREKTNA SINTEZA NANOSTRUKTURNOG PLEMENITOG METALA NA UGLJENIČNOJ OSNOVI POMOĆU HIDROTERMALNOG PROCESA}

Nanostrukture plemenitih metala (Pt i Ag) na ugljeničnom materijalu, kao nosaču, su napravljene, polazeći od fruktoze i rastvora soli plemenitih metala $\left(\mathrm{H}_{2} \mathrm{PtCl}_{6} \times 6 \mathrm{H}_{2} \mathrm{O}\right.$ ili $\left.\mathrm{AgNO}_{3}\right)$ pri hidrotermalnim uslovima. Komercijalna fruktoza $\left(\mathrm{C}_{6} \mathrm{H}_{12} \mathrm{O}_{6}\right)$ deluje kao izvor ugljenika i redukujući agens, a soli plemenitih metala, kao izvor metala, koji treba da se inkorporira u novonastalu strukturu ugljeničnog materijala. Kristalita struktura je ispitivana pomoću difrakcije X-zraka (XRD) a morfologija je ispitivana pomoću skanirajuće elektronske mikroskopije (SEM). Veličina kristalita deponovanih čestica se računa iz širine linije Bragg-ovog pika koristeći Scherrer-ov metod. Svi XRD uzorci jasno pokazuju pet karakterističnih pikova površinski centrirane kristalne rešetke (fcc) i za kristalite Pt i za kristalite Ag. Dobijeni kristaliti Pt imaju velišinu manju od $5.5 \mathrm{~nm}$, dok su veličine kristalita Ag oko 32 i 34nm.

Ključne riječi: hidrotermalni proces, platina, srebro, nanostruktura, veličina kristalita

Naucni rad

Rad primljen: 16. 05. 2015.

Rad prihvacen: 19. 07. 2015.

Rad je dostupan na sajtu: www.idk.org.rs/casopis 